\title{
Bioremediation of Iron on Diamond Post Mining Soil Using Compost Made from Cow Manure and Traditional Market Organic Waste
}

\author{
Rizqi Puteri Mahyudin ${ }^{1 *}$, Muhammad Firmansyah', \\ Melisa Anggraini Purwanti', Dina Najmina ${ }^{1}$ \\ 1 Department of Environmental Engineering, Faculty of Engineering, Lambung Mangkurat University, J. \\ Jenderal Achmad Yani Km. 35,5 Banjarbaru 70714, South Kalimantan, Indonesia \\ * Corresponding author's e-mail: rizqiputeri@ulm.ac.id
}

\begin{abstract}
The purpose of this research was to improve the diamond post-mining soil quality using a bioremediation composting method based on the cow manure and organic waste from a traditional market. This research was conducted for: 1) identifying the conditions for temperature, $\mathrm{pH}$ and moisture during the composting process; 2) analyzing the difference of variations in composition and the best composting durations. The bioremediation method used is open windrow composting, divided into four composition variations, namely variation A (100\% soil); B (75\% soil: $25 \%$ compost); C (50\% soil: $50 \%$ compost); D ( $25 \%$ soil: $75 \%$ compost). The variations of composting duration are $15^{\text {th }}$ and $30^{\text {th }}$ days. From the result of two-way ANOVA test, it can be concluded that there is no significant difference in the decrease of $\mathrm{Fe}$ value due to the variations in composition ratio and duration of composting.
\end{abstract}

Keywords: bioremediation, composting, cow manure, Fe, market organic waste.

\section{INTRODUCTION}

The environmental damage is caused by mining activities. This is because the mining activities such as coal, metal, gold or diamond mining produces hazardous and toxic waste that contain heavy metals. The content of heavy metals is what makes the environment damaged. In order to minimize the environmental damage, it is necessary to manage the mining waste products to mitigate environmental damage that will occur (Sidabutar, 2013). However, repairing the soil damaged by heavy metal waste requires a long time. Besides, the recovery of soil damage can be accelerated by adding bacteria into the polluted soil, which is also called bioremediation (Sudaryono, 2007).

The diamond mining in Banjarbaru in Cempaka District is a form of community mining. Community mining involves small-scale mining operations that are carried out by local communities. These mining activities affect the chemical, physical, and biological properties of the soil. The physical constraints include, e.g. damaged soil structure, while the chemical constraints - a low $\mathrm{pH}$ and high iron ( $\mathrm{Fe})$ levels.

On the basis of the author's preliminary study in February 2019, the diamond mining in the Tiung River village, Cempaka sub-district, contributed to a high $\mathrm{Fe}$ heavy metal content in the soil, namely $1755.83 \mathrm{mg} / \mathrm{kg}$. If the concentration of $\mathrm{Fe}$ in the soil that is $30 \mathrm{ppm}$ it can poison the plants (Tadano and Yoshida, 1978; Yoshida, 1981), so it is not good for the agricultural soil. Because Fe is an essential metal that often is toxic to humans in large doses, eventually causing death (Hakiki, 2018).

One method of bioremediation is composting, which is a technique of removing the harmful pollutants from the environment. The main principle of bioremediation process involves increasing the microbial activity through controlling temperature, $\mathrm{pH}$, and humidity. The bioremediation techniques using compost made from organic waste can be employed to overcome the damage to soil affected by pollutants (Mizwar, 2014). The compost addition can thus be considered as a 'superbioaugmentation' with a complex natural mixture 
of degrading microorganisms, combined with a 'biostimulation' by nutrient containing readily to hardly degradable organic substrates. It also improves the abiotic soil conditions, thus enhancing the microbial activity in general (Kästner and Miltner, 2016). An organic fertilizer or compost has several advantages compared to an inorganic fertilizer. These advantages include complete micro and macro nutrients, even though the amount is small and can improve the soil structure by loosening and increasing the soil availability. Compost is a fertilizer that comes from the weathering process of materials in the form of leaves, straw, reeds, grass, animal waste, organic waste and others. Compost has the advantage of being able to improve the soil physical properties, as well as the chemical and biological ones.

\section{MATERIAL AND METHOD}

This research was conducted from April to July 2019. The soil sampling was done in exdiamond mining soil in Cempaka District. Bioremediation with the composting method was conducted at the Education Techno Park (ETP) of the Engineering Faculty Lambung Mangkurat University. Compost fertilizer and soil sample testing are carried out at the Banjarbaru Center for Environmental Health and Disease Control (BBTKLPP) Laboratory.

The materials used in this research were 300 $\mathrm{kg}$ of ex-mining soil, $180 \mathrm{~kg}$ of cow manure compost and $180 \mathrm{~kg}$ of half processed organic waste. The used tools included shovels, hoes, analytical scales, gunny sacks, tarps, trash bags, soil survey instruments, soil testers, cameras as research documentation tools, and other tools that supported this research.

The research design used is Complete Random Design with 4 variations of composition and 3 replications. The variations of soil and compost ratio namely: $100 \%$ soil as a control, A (75\% soil: $25 \%$ compost), B (50\% soil: $50 \%$ compost), C (25\% soil: $75 \%$ compost). Each pile contained $40 \mathrm{~kg}$ soil and compost mixture. The heigth of each pile is $30^{\text {th }} \mathrm{cm}$ and the distance from each pile is $30^{\text {th }} \mathrm{cm}$.

The composting process was carried out for $15^{\text {th }}$ and $30^{\text {th }}$ days. The measurement of temperature, $\mathrm{pH}$ and humidity was done every day at $13.00-14.00 \mathrm{AM}$ at three points of the pile (top, middle, bottom) using a soil survey instrument and soil tester. The research data were presented in graphical form to identify the $\mathrm{pH}$, temperature and humidity conditions.

The analysis of temperature, $\mathrm{pH}$, humidity data, and Fe value were described in a grafic form. Two-way ANOVA test was conducted to analyze the difference of Fe value from the treatment, followed by an LSD test using SPSS 17.1 for Windows to see the best variation in composition variations and composting durations in the open windrow composting system.

\section{RESULT AND DISCUSSION}

\section{Bioremediation composting conditions}

The graphs of the changes in the compost temperature in each variation namely $100 \%$ soil treatment, $75 \%$ soil: $25 \%$ compost, $50 \%$ soil: $50 \%$ compost, and $25 \%$ soil: $75 \%$ compost, as can be seen in Figures 1 and 2. Figure 1 indicated that in the beginning of the of composting bioremediation, the highest temperature is $35.33^{\circ} \mathrm{C}$ (in $25 \%$ soil : $75 \%$ compost ratio). While the lowest temperature is in $100 \%$ soil variation. Figure 2 shows that the changes in composting bioremediation temperature made from organic waste is higher than the cow manure compost. The highest temperature found on the $5^{\text {th }}$ day at variation of $50 \%$ soil: $50 \%$ compost ratio.

The graphs of the changes in the compost temperature shows that the bacteria in the open windrow composting process are classfied as mesophilic because such bacteria lived in the temperature range of $10-40{ }^{\circ} \mathrm{C}$. The mesophilic bacteria play a role in reducing the particle size of organic matter so that the surface area increases and accelerates the composting process (Widyawati et al., 2015). The mesophilic condition is more effective because the activity of microorganisms is dominated by bacteria and fungi. The temperature in each treatment does not reach the thermophilic phase $\left(45-60^{\circ} \mathrm{C}\right)$ because the heigth of the pile is too low that has an impact the compost pile lose heat faster, so that high temperatures cannot be reached (Widarti, 2015).

The temperature at the top of the pile is higher than the middle and bottom point. In turn, the lowest temperature was obtained on the $25^{\text {th }}$ day in variation of $100 \%$ soil, $50 \%$ soil: $50 \%$ compost, and $75 \%$ soil: $25 \%$ compost ratio.

The graphs of $\mathrm{pH}$ changes of compost pile can be seen in Figures 3 and 4. Figure 3 shows the results of the analysis on the $\mathrm{pH}$ value of 


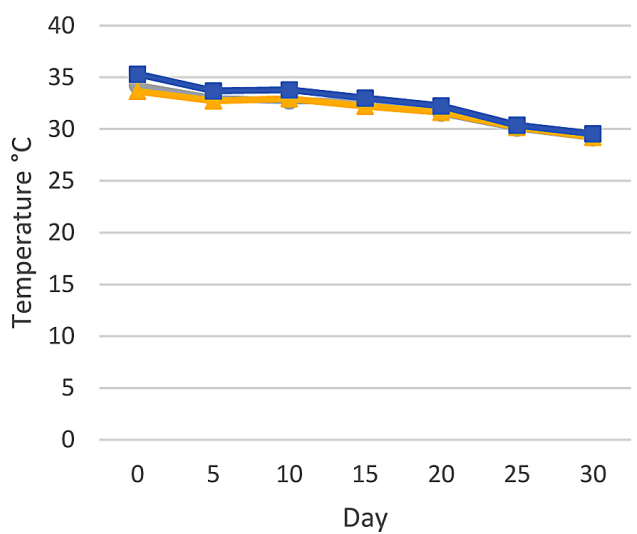

A ( $75 \%$ soil : $25 \%$ compost)

$-B(50 \%$ soil : $50 \%$ compost )

$\longrightarrow c(25 \%$ soil : $75 \%$

compost)

Figure 1. Temperature changes of bioremediation of cow manure made compost

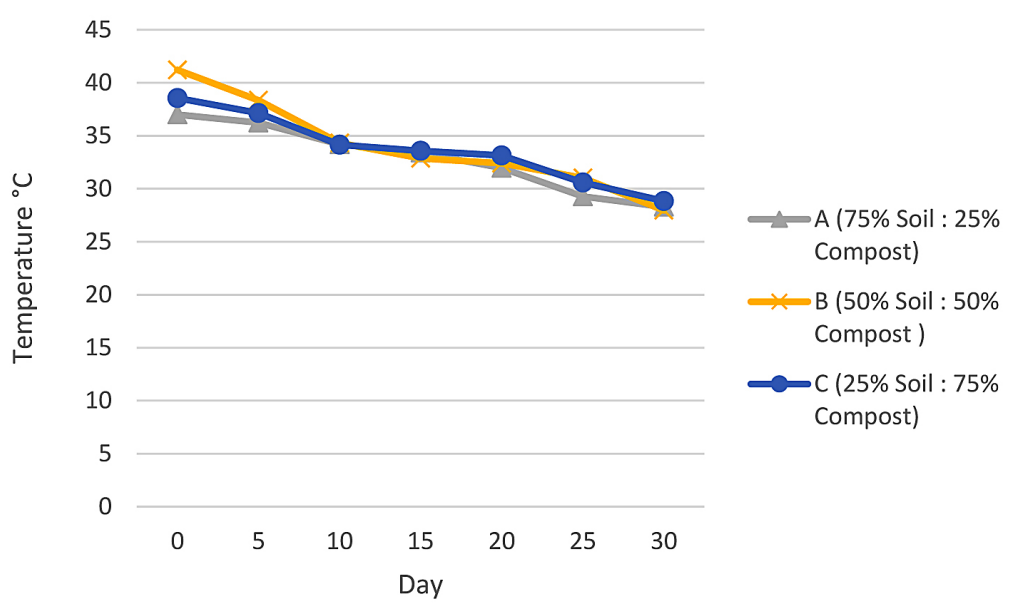

Figure 2. Temperature changes of bioremediation of market organic waste compost

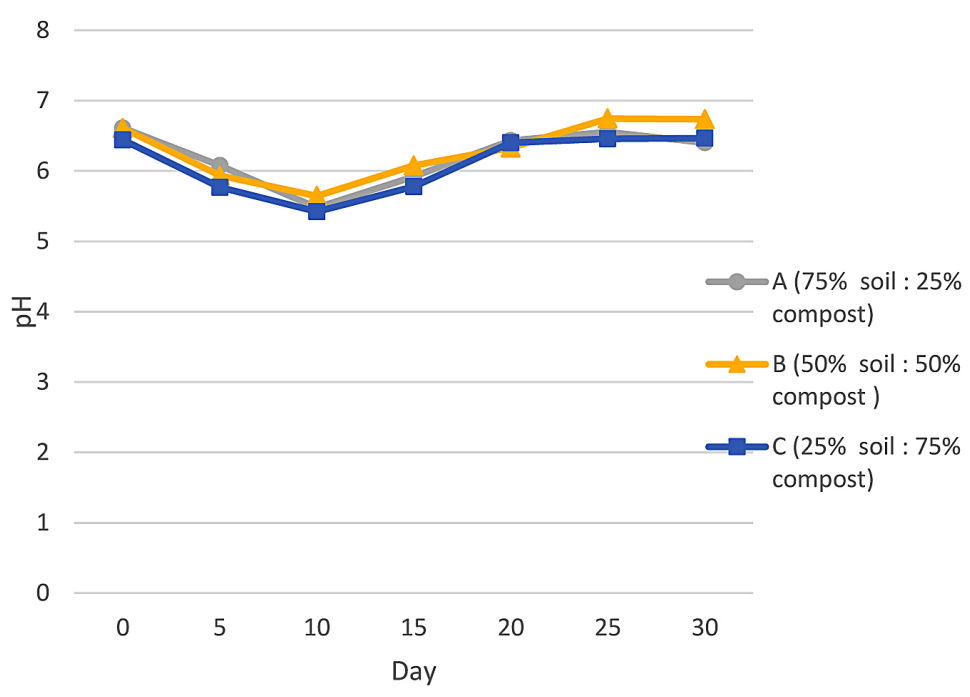

Figure 3. $\mathrm{pH}$ changes of bioremediation of cow manure compost

composting bioremediation based on the cow manure. It was observed that during the composting bioremediation process, there was a fluctuation in the $\mathrm{pH}$ value. In the composting process, the $\mathrm{pH}$ value needs to be considered because it could affects the microorganism activity in it. The $\mathrm{pH}$ value during the composting bioremediation with the values range from 5.1 to 7.00 .

In Figure 4, the observation of the changes in $\mathrm{pH}$ shows that on $1^{\text {st }}$ day and $2^{\text {nd }}$ day the $\mathrm{pH}$ value is low, the $\mathrm{pH}$ value becomes relatively stable starts on the $3^{\text {rd }}$ day until the $30^{\text {th }}$ day. 


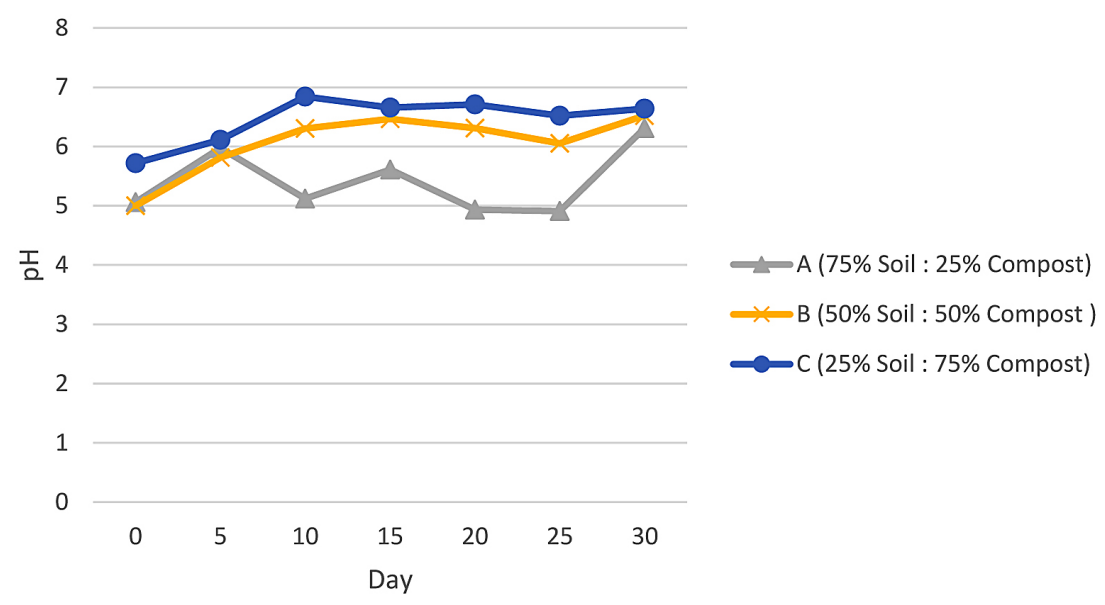

Figure 4. pH changes of bioremediation of market organic waste compost

The composting process causes changes in the organic material and the $\mathrm{pH}$ itself. The $\mathrm{pH}$ value during the composting period greatly influences the growth of the microorganisms. At the beginning of the composting process on the $1^{\text {st }}$ day to the $2^{\text {nd }}$ day, the $\mathrm{pH}$ shows a value ranging from 5.5-5; then there was an increase in $\mathrm{pH}$ on the $14^{\text {th }}$ day with a $\mathrm{pH}$ value of 7 . However, on the $15^{\text {th }}$ day, the $\mathrm{pH}$ decreased again to 5.9.

A good strirring during the composting process can maintain the $\mathrm{pH}$ value under neutral $\mathrm{pH}$ conditions. The composting process causes changes in the organic material and the $\mathrm{pH}$ itself. For example, the acid release process causes a decrease in $\mathrm{pH}$ (acidification), while the production of ammonia from nitrogen-containing compounds increases the $\mathrm{pH}$ in the early phases of the composting process.

The graph of the changes in compost humidity can be seen in Figures 5 and 6. Figure 5 shows that in $75 \%$ soil: $25 \%$ compost ratio, the compost humidity is in between $31-60 \%$. In $50 \%$ of soil
$50 \%$ compost ratio, the pile has a humidity between $51-60 \%$ (the optimum conditions), whereas in $25 \%$ of soil: $75 \%$ of compost the humidity reaches $53-80 \%$.

In Figure 6 on $75 \%$ soil: $25 \%$, the compost humidity $54.44-65.56 \%$. In $50 \%$ of soil: $50 \%$ compost has a humidity of $56.00-68.33 \%$, while in $25 \%$ of soil: $75 \%$ of compost the humidity reaches $63.33-70 \%$. On the basis of the graph above, it is known that on the first day of the composting process, variations in $100 \%$ of the soil have a normal moisture content $(47 \%)$, while in other variations it has a moisture content in the range of 60$70 \%$. However, on the third day, the water content in the $100 \%$ variation of soil has decreased below $40 \%$, while other variations have remained stable in the range of $60-70 \%$. Therefore, on the 5 th day of strirring, water is added to keep the pile moist and not too dry.

If the compost pile is too moist, the decomposition process will disturbed. This happen because the water content will cover the air cavity

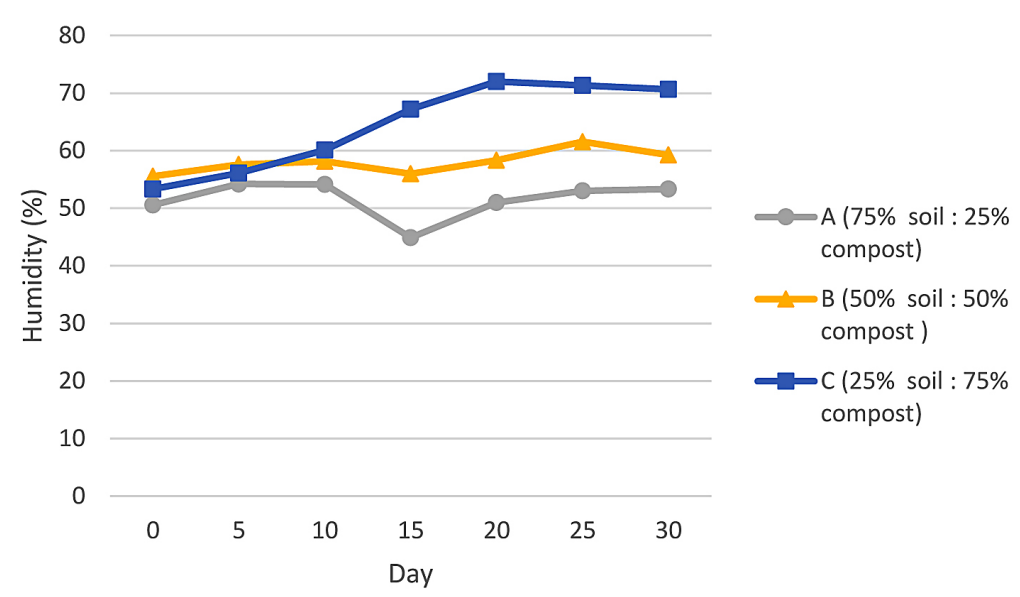

Figure 5. Moisture changes of bioremediation of cow manure compost 


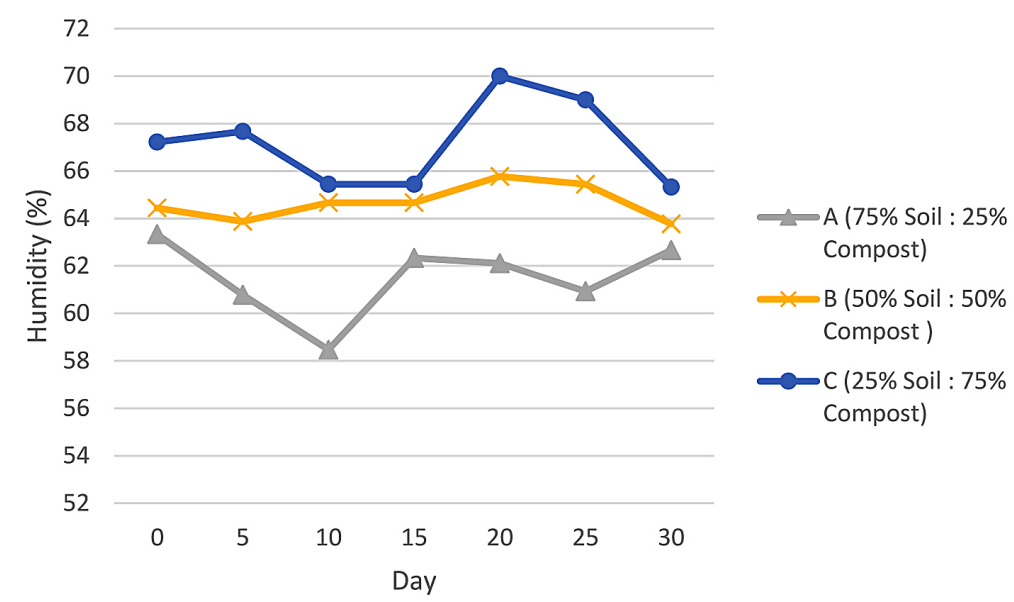

Figure 6. Humidity changes of bioremediation of market organic waste compost

in the pile. This condition will cause the composting process will take longer. If the humidity is too low, the efficiency of degradation will decrease due to the lack of water to dissolve the organic material that will be degraded by microorganisms as a source of energy (Widarti, 2015).

\section{Fe value in composition variations}

The comparison of the Fe value in the composition of $75 \%$ soil: $25 \%$ compost, $50 \%$ soil: $50 \%$ compost, $25 \%$ soil: $75 \%$ compost made from the cow manure and market organic waste with bioremediation duration of composting day can be seen in Figures 7, 8, 9.

Figure 7 shows that $\mathrm{Fe}$ value in the compost ( $75 \%$ soil: $25 \%$ compost) made from the cow manure on first day is higher $(788.68 \mathrm{mg} / \mathrm{kg})$ than the compost made from organic waste $(696.86$ $\mathrm{mg} / \mathrm{kg}$ ). On the $15^{\text {th }}$ day, Fe value of the compost made from the cow manure increased, while $\mathrm{Fe}$ value of the compost made from organic waste decreased. On the 30 th $^{\text {th }}$ day, Fe value of the compost pile made from the cow manure decreased significantly as much as $822.31 \mathrm{mg} / \mathrm{kg}$. Fe value of the compost pile made from organic waste decreased as much as $182.72 \mathrm{mg} / \mathrm{kg}$.

Figure 8 (50\% soil: $50 \%$ compost ratio) shows that Fe value of compost made from cow manure on first day is lower $(885.68 \mathrm{mg} / \mathrm{kg})$ than the compost made from organic waste $(955.31 \mathrm{mg} /$ $\mathrm{kg}$ ). On the $15^{\text {th }}$ day, the compost made from the cow manure and that made from organic waste decreased by $39.9 \mathrm{mg} / \mathrm{kg}$ and $206.66 \mathrm{mg} / \mathrm{kg}$, respectively while on the $30 \mathrm{th}^{\text {th }}$ day the cow manure based compost decreased by $287.65 \mathrm{mg} / \mathrm{kg}$ so that the value of Fe became $528.13 \mathrm{mg} / \mathrm{kg}$ and the compost based on organic waste decreased by $335.5 \mathrm{mg} / \mathrm{kg}$ so that the value of $\mathrm{Fe}$ became $413.15 \mathrm{mg} / \mathrm{kg}$.

Figure 9 (25\% soil: $75 \%$ compost ratio) shows that bioremediation of the iron $(\mathrm{Fe})$ value using the compost made from the cow manure on $1^{\text {st }}$ day is lower $(825.17 \mathrm{mg} / \mathrm{kg})$ than using

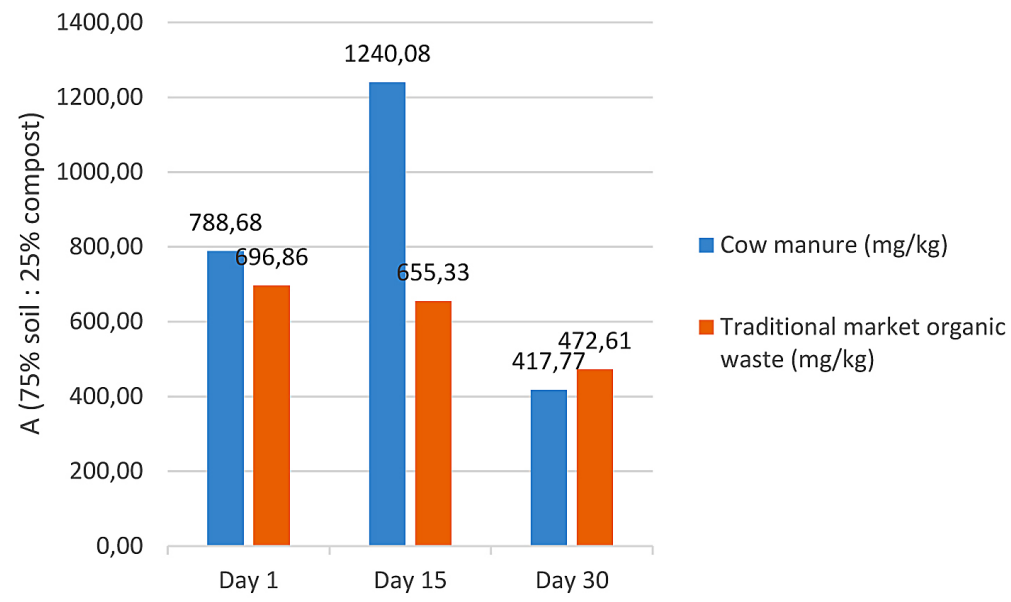

Figure 7. Fe value in the composition: $75 \%$ of soil and $25 \%$ of compost 


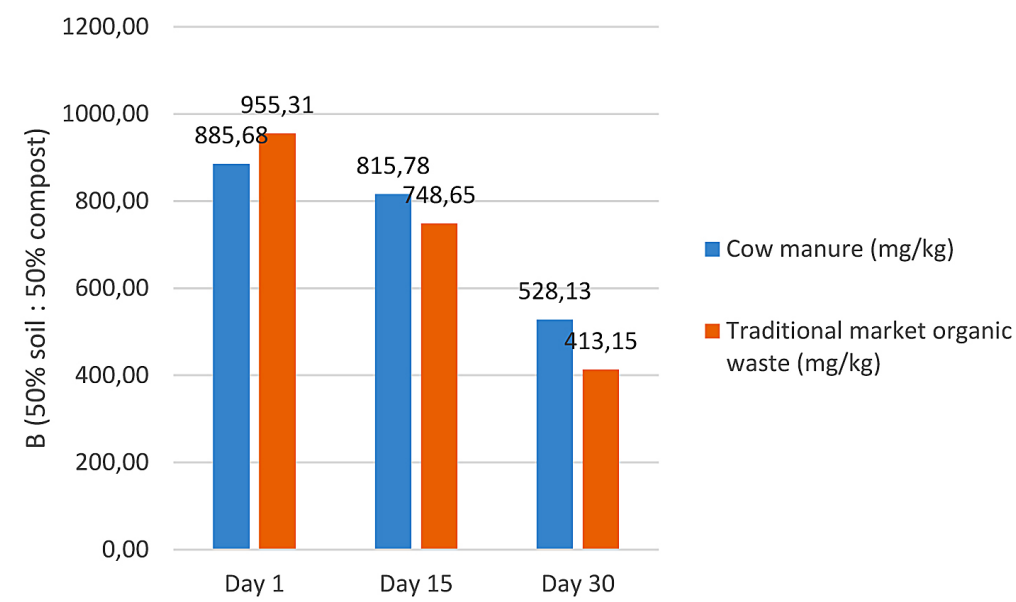

Figure 8. Fe value in the composition: $50 \%$ of soil and $50 \%$ of compost

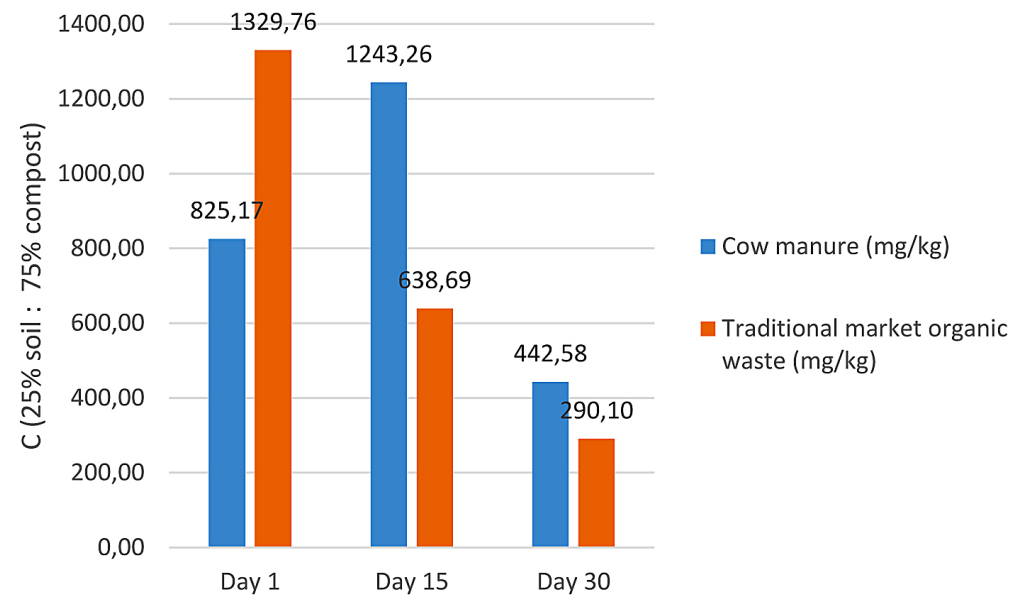

Figure 9. Fe value in the composition: $25 \%$ of soil and $75 \%$ of compost

the compost made from organic waste (1329.76 $\mathrm{mg} / \mathrm{kg}$. On the $30^{\text {th }}$ day, $\mathrm{Fe}$ value were decreased from both materials compost. On the $30^{\text {th }}$ day the compost made from the cow manure decreased by $800.68 \mathrm{mg} / \mathrm{kg}$ so that the value of Fe became $442.58 \mathrm{mg} / \mathrm{kg}$ and that made from organic waste decreased $348.59 \mathrm{mg} / \mathrm{kg}$ so that the value of $\mathrm{Fe}$ became $290.10 \mathrm{mg} / \mathrm{kg}$.

On the basis of these three compositions, there are advantages and disadvantages during the bioremediation composting process based on the cow manure and organic market waste. The increase occurred on the $15^{\text {th }}$ day based on the cow manure, but on the $15^{\text {th }}$ day the compost based on cow manure with a composition of 50 soil: $50 \%$ compost experienced a decrease while on the $15^{\text {th }}$ day the organic waste based compost of the third composition decreased. An increase on the $15^{\text {th }}$ day in the compost made from cow manure occurred because the bacteria experienced a point of saturation, so that the tendency of bacteria to bind heavy metals was reduced even tended to remove the heavy metal that has been absorbed (Khoiroh, 2014). Because there is still a process of reshuffle and release of $\mathrm{Fe}$, it moves freely; thus, the soil is dominated by Fe (Ariyadi, 2018). The Fe decrease occurred on the market organic waste based compost on the $15^{\text {th }}$ day and $30^{\text {th }}$ day while on the cow based waste compost it decreased on the $15^{\text {th }}$ day with $50 \%$ soil composition: $50 \%$ compost and $30^{\text {th }}$ day all composition. The decrease occurred during the composting bioremediation process due to the presence of the bacteria that are able to adsorb heavy metals in their cell walls (Khoiroh, 2014). The decrease in $\mathrm{Fe}$ is due to the activity of microorganisms and the absorption of $\mathrm{Fe}$ by organic fertilizers that form chelate bonds. Thu,s the presence of the organic material from the compost based on cow manure is able to absorb the Fe value in the soil. The chelate bond binds the other $\mathrm{Fe}^{3+}$ ions, the chelation takes the free $\mathrm{Fe}$ ions from the soil causing the $\mathrm{Fe}$ level in the solution to decrease (Yowono, 2010). The 
organic fertilizer adsorbs and binds the heavy metals by cation exchange, forming electrostatic bonds, complex bonds (Prasetiyono, 2015).

This is in accordance with Widyawati's research (2015). Bioremediation is a process of pollutant recovery by utilizing the services of living things such as microbes (bacteria, fungi, yeast) produced in their metabolic processes. As soil dwellers, microbial life is always directly affected by the changes that occur in the soil. In ex-mining soil, the soil changes (physical, chemical, and biological) occur drastically, so that in these ecosystems the microbes must adapt to the new environment, or become extinct. One mechanism of adaptation is to change the expression of genes so that the activity of enzymes and proteins allows them to continue living in the environment. Some microbial mechanisms adapt to the mined soil contaminated with metals, including the microbes capable of using metals as an energy source and presenting metal in the form of reducing metals to non-toxic forms. This microbial ability can be used in the process of metal detoxification, i.e. bioremediation.

\section{Analysis of Fe value using two way ANOVA test}

The results of the analysis of composting bioremediation research based on the cow manure, the smallest Fe value during the composting bioremediation process based on the cow manure is $417.77 \mathrm{mg} / \mathrm{kg}$ with a composition variation of $75 \%$ Soil: $25 \%$ compost with a period of $30^{\text {th }}$ days. On the basis of the two-way ANOVA test, it can be concluded that there is no significant difference in the decrease in the Fe value due to the variations in composition and the length of composting bioremediation based on the cow manure.

The results of the composting bioremediation process analysis based on organic waste indicate that the smallest $\mathrm{Fe}$ value is $290.10 \mathrm{mg} / \mathrm{kg}$ with a variation of the composition of $25 \%$ soil: $75 \%$ Compost. The Fe value of $290.10 \mathrm{mg} / \mathrm{kg}$ is below the threshold value of agricultural soil, according to Yoshida (1978).

\section{CONCLUSION}

1. The temperature conditions of the four compositions during the composting process decreased until the $30 \mathrm{th}^{\text {th }}$ day. The $\mathrm{pH}$ value in $100 \%$ of the soil remained stable at neutral values (5.5-7). The humidity in the control of $100 \%$ of the soil was below $40 \%$, low enough for humidity because the optimal value for composting is $50-60 \%$.

2. Based on two-way ANOVA test, it can be concluded that there is no significant difference in the decrease in Fe value due to the variations in the composition and duration of day composting bioremediation based on the cow manure and organic market waste. The composting bioremediation made from organic market waste composition shows the best result (75\% compost: $25 \%$ of soil on the $30 \mathrm{th}^{\text {th }}$ day, with a value of $\mathrm{Fe}$ of 290.10 and removal amount of Fe decrease of $78.18 \%$ ).

\section{Acknowledgements}

This research supported by PNBP of Engineering Faculty Lambung Mangkurat University South Kalimantan Indonesia.

\section{REFERENCES}

1. Hakiki I.A. 2018. Analysis of heavy metals (Pb, Fe, $\mathrm{Zn}$ ) in coal former soil and its benefits as an environmental chemical handout on soil pollution material. Thesis. Faculty of Teacher Training and Education, University of Jambi.

2. Indrayantie R.E. 2011. Post-mining impacts on soil and water quality in Palam Village, Cempaka District, Banjarbaru City, South Kalimantan. Journal of Tropical Forests, 12(31), 15-26.

3. Kästner M., Miltne A. 2016. Application of compost for effective bioremediation of organic contaminants and pollutants in soil. Appl Microbiol Biotechnol, 100, 3433.

4. Khoiroh Z. 2014. The role of heavy metal lead $(\mathrm{Pb})$ in Lapindo mud using a mixture of bacteria (Pseudomonas pseudomallei and Pseudomonas aeruginosa). Undergraduate thesis, Maulana Malik Ibrahim State Islamic University.

5. Mizwar A. and Trihadiningrum Y. 2014. Potential of bioremediation of polycyclic aromatic hydrocarbons contaminated soil from coal by composting. Proceedings of the National Waste Management II Seminar, Sepuluh November Institute of Technology, Surabaya, 251-264.

6. Prasetiyono E. 2015. Ability of Compost in reducing lead metal heavy content $(\mathrm{Pb})$ in fish culture media. Journal of Aquatics, 6(1), 21-29.

7. Sidabutar J. 2013. Changes in soil chemical characteristics in the former mine reclamation model 
of Pt. Antam Ubpe Pongkor. Thesis. Final Project Silviculture Department, Faculty of Forestry. Bogor Agricultural Institute. Bogor.

8. Sudaryono, 2007. Effect of kandangan fertilizer on $\mathrm{Cr}$ absorption in peanuts. Journal of Environmental Engineering, 8(1), 48-53.

9. Widarti B.N., Wardhini W.K., and Sarwono E. 2015. Effect of C/N Ratio of Raw Materials on Making Compost from Cabbage and Banana Skins. Journal of Process Integration, 5 (2), 75-80.
10. Widyawati E., Mansur I., Kusmana C., Anas I. and Santoso E. 2005. Utilization of the paper industry sludge as an agent for soil reforming in coal former soil. Journal of Forest Research and Nature Conservation, 2(2), 127-134.

11. Tadano T. and Yoshida S. 1978. Chemical changes in submerged soils and their effect on rice growth. IRRI, Los Banos. Philippines, 399-420.

12. Yoshida S. 1981. Fundamentals of rice crop science. IRRI, Los Banos. pp. 269. 